\title{
Modelling diatom and Phaeocystis blooms and nutrient cycles in the Southern Bight of the North Sea: the MIRO model
}

\author{
C. Lancelot $^{1, *}$, Y. Spitz ${ }^{2}$, N. Gypens ${ }^{1}$, K. Ruddick ${ }^{3}$, S. Becquevort ${ }^{1}$, V. Rousseau ${ }^{1}$, \\ G. Lacroix $^{3}$, G. Billen ${ }^{4}$ \\ ${ }^{1}$ Université Libre de Bruxelles, Ecologie des Systèmes Aquatiques, CP-221, Boulevard du Triomphe, 1050 Brussels, Belgium \\ ${ }^{2}$ Oregon State University, College of Oceanic and Atmospheric Sciences, 104 COAS Admin. Bldg., Corvallis, \\ Oregon 97331, USA \\ ${ }^{3}$ Royal Belgian Institute of Natural Sciences, Management Unit of the North Sea Mathematical Models, Gulledelle 100, \\ 1200 Brussels, Belgium \\ ${ }^{4}$ Université Pierre \& Marie Curie (Paris VI), UMR-CNRS 7619 Sisyphe, 4 Place Jussieu, 75005 Paris, France
}

\begin{abstract}
The link between anthropogenic nutrient loads and the magnitude and extent of diatom and Phaeocystis colony blooms in the Southern Bight of the North Sea was explored with the complex ecosystem model MIRO. The model was adapted for resolving the changing nutrient loads, the complex biology of the bloom species and the tight coupling between the benthic and pelagic compartments that characterise this shallow coastal shelf sea ecosystem. State variables included the main inorganic nutrients (nitrate $\left[\mathrm{NO}_{3}\right]$, ammonium $\left[\mathrm{NH}_{4}\right]$, phosphate $\left[\mathrm{PO}_{4}\right]$ and dissolved silica [DSi]), 3 groups of phytoplankton with different trophic fates (diatoms, nanophytoflagellates and Phaeocystis colonies), 2 zooplankton groups (copepods and microzooplankton), bacteria, and 5 classes of detrital organic matter with different biodegradability. The capability of the MIRO model to properly simulate the observed SW-NE gradient in nutrient enrichment and the seasonal cycle of inorganic and organic $\mathrm{C}$ and nutrients, phytoplankton, bacteria and zooplankton in the eastern English Channel and Southern Bight of the North Sea is demonstrated by running the model for the period from 1989 to 1999. The MIRO code was implemented in a simplified multi-box representation of the hydrodynamic regime. These model runs give the first general view of the seasonal dynamics of Phaeocystis colony blooms and nutrient cycling within the domain. C, N and P budget calculations show that (1) the coastal ecosystem has a low nutrient retention and elimination capacity, (2) trophic efficiency of the planktonic system is low, and (3) both are modulated by meteorological forcing.
\end{abstract}

KEY WORDS: North Sea $\cdot$ Eutrophication · Phaeocystis $\cdot$ Carbon budgets $\cdot$ Nutrients $\cdot$ Ecological modelling

\section{INTRODUCTION}

The coastal zone, i.e. the interface between land, ocean and atmosphere, plays a major role as a recipient of large amounts of nutrients from human activities, including industrial effluents, agricultural runoff, and municipal sewage. Effects of anthropogenic coastal eutrophication often appear as qualitative changes in pelagic food webs, e.g. proliferation of harmful or toxic phytoplankton species, extinction of key species at higher trophic levels, and reduced yields of harvestable fish or invertebrate populations. These alterations of ecosystem structure and function are primarily driven by changes in nutrient ratios available to coastal phytoplankton, specifically by enrichment in nitrogen and phosphorus, compared to 


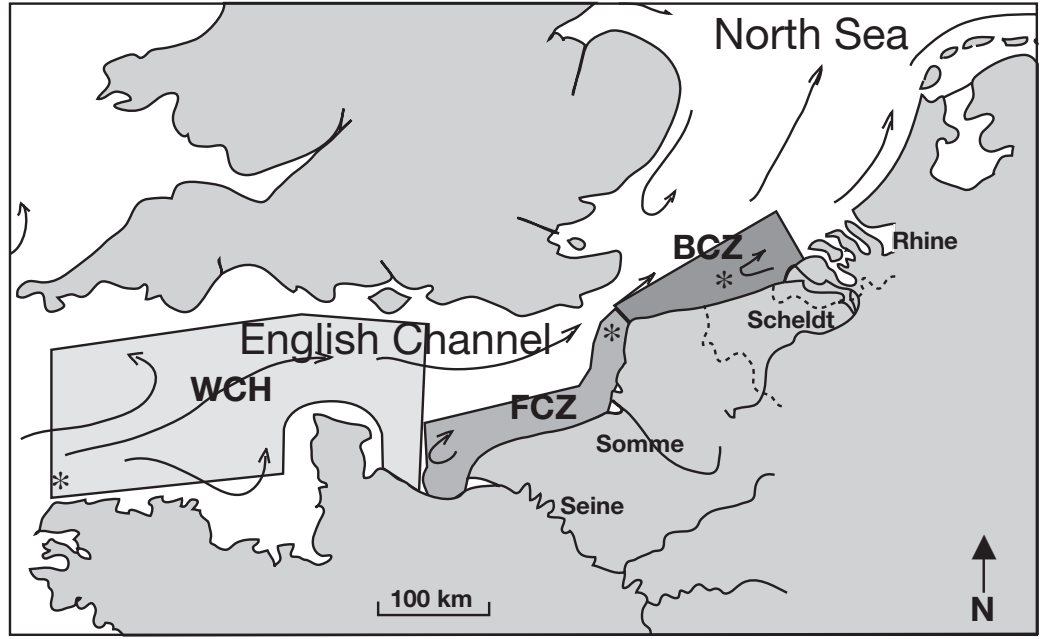

Fig. 1. Implementation domain of MIRO in the English Channel and Southern Bight of the North Sea. Arrows indicate the Atlantic water inflow and discharge of main rivers. *Monitoring stations. WCH: western Channel; FCZ: French coastal zone; BCZ: Belgian coastal zone

but enriched in nitrogen and phosphorus (Rousseau et al. 2002). The effects of Phaeocystis dominance over diatoms in spring on the structure and function of the coastal ecosystem, and hence on the overall yield of harvestable biological resources, are not yet quantified. Changes in planktonic food webs have been reported by Hansen et al. (1994) and Rousseau et al. (2000). For instance, the dominance of large Phaeocystis colonies, which are unpalatable for mesozooplankton (Gasparini et al. 2000), stimulates a microbial food web initiated by microprotozoa grazing on Phaeocystis cells originating from disrupted colonies (Weisse \& Scheffell-Moser 1990). Part of the Phaeocystis-derived production is, however, returned to the classical food web through mesozooplankton feeding on the protozoa

the N:Si:P (16:16:1) requirements of diatoms (Officer \& Ryther 1980). Anthropogenic inputs thus stimulate the development of opportunistic non-siliceous phytoplankton, and this may be accompanied by major changes in the flows of energy and materials within the system, affecting natural resources (water quality and harvestable biological resources), nutrient retention, carbon exportation/sequestration and greenhouse gas emissions (e.g. Turner et al. 1998, Olsen et al. 2001).

The Belgian Coastal Zone (BCZ) in the Southern Bight of the North Sea is a nutrient-enriched coastal sea where massive algal blooms (biomass $>30 \mathrm{mg}$ chl $a \mathrm{~m}^{-3}$ ) occur every spring. The BCZ is a highly dynamic system where waters of Atlantic origin are mixed with freshwater river inputs (Laevastu 1963; Fig. 1). Overall nutrient enrichment in the BCZ reflects the cumulative inputs from atmospheric and riverine sources (primarily from the River Scheldt), local benthic remineralization and in-flowing Atlantic waters, themselves enriched by nutrient loads (primarily from the River Seine). The relative importance of these different sources in the BCZ is not accurately known, but atmospheric loads are negligible (less than $1 \%$; Rousseau et al. 2004). Eutrophication along the continental coastline of the Southern Bight of the North Sea leads to high-biomass algal blooms (mainly the Haptophycea Phaeocystis globosa) that spread over the entire area along a SW-NE gradient in spring (Lancelot et al. 1987). Current knowledge indicates that after a modest early spring bloom of diatoms, massive development of Phaeocystis colonies is sustained by freshwater inputs deficient in silicon
(Hansen 1992). Recent budget calculations (Rousseau et al. 2000) have concluded that the trophic efficiency of the microbial pathway associated with the Phaeocystis colony bloom is low (3\%), although protozoa made up $28 \%$ of the copepod diet.

Due to the complexity of interactions between planktonic organisms, the link between nutrient inputs and coastal ecosystem function cannot be understood by simple correlation between events. Mechanistic models, which are based on chemical and biological principles and describe ecosystem carbon and nutrient cycles as a function of environmental forcing, are ideal tools to analyse this complexity. When they are validated, these models help to understand the dynamics of the ecosystem and assess the magnitude and extent of algal blooms and related impacts in response to changes in land-based nutrient inputs and climate.

In this study we detail the structure and parameterisation of the current MIRO model, a modified version of the Lancelot et al. (1997) model describing C, N, P and Si cycling in the Phaeocystis-dominated eastern English Channel and Southern Bight of the North Sea. The upgraded version is based on new observations and process studies obtained between 1996 and 1999 at Stn 330 in the central BCZ (Fig. 1). The prediction capability of the upgraded MIRO model is tested through its ability to reproduce observations collected in the Southern Bight of the North Sea during the last decade (1989 to 1999) with particular focus on the central BCZ. Further analysis of model results allows estimation of the trophic efficiency of the planktonic food web as well as the nutrient retention and elimination capacity of the BCZ. 


\section{MATERIALS AND METHODS}

Model description. MIRO describes and predicts C, N, P and Si cycling through aggregated components of the coastal ecosystem, over seasons and years, in response to physical and nutrient forcing. The MIRO parameterisations are based on physiological principles. The model synthesises some $25 \mathrm{yr}$ of ecophysiological investigations in the region and describes current knowledge on the kinetics and factors controlling the main auto- and heterotrophic processes involved in the functioning of the coastal marine ecosystem.

A total of 32 state variables and 28 processes linking them were selected, based on our knowledge of the structure and functioning of Phaeocystis-dominated ecosystems (Fig. 2). The model results from the integration of 4 modules describing the dynamics of phytoplankton (3 groups), zooplankton (2 groups), bacteria, and dissolved and particulate organic matter (DOM: monomers and 2 classes of biodegradability;
POM: 2 classes of biodegradability) degradation and nutrient (nitrate $\left[\mathrm{NO}_{3}\right]$, ammonium $\left[\mathrm{NH}_{4}\right]$, phosphate $\left[\mathrm{PO}_{4}\right]$ and dissolved silica [DSi]) regeneration in the water column and the sediment (Fig. 2). State variables, processes and conservation equations are described in Appendices 1 to 3. The mathematical formulation of processes is given in Appendix 4 (Appendices are available at www.int-res.com/journals/suppl/ appendix_lancelot.pdf).

Phytoplankton: The phytoplankton module considers 3 phytoplankton groups: diatoms (DA), autotrophic nanoflagellates (NF) and Phaeocystis colonies (OP). Due to their trophic fate, free-living cells and colonies of Phaeocystis were considered as separate state variables, even though they merely constitute different life stages of the same organism (e.g. Rousseau et al. 1994). Phaeocystis free-living cells were included in NF, while Phaeocystis colonies were described by the sum of 2 state variables: colonial cells (OPC) and the polysaccharide matrix (OPM) in which the cells are embed-

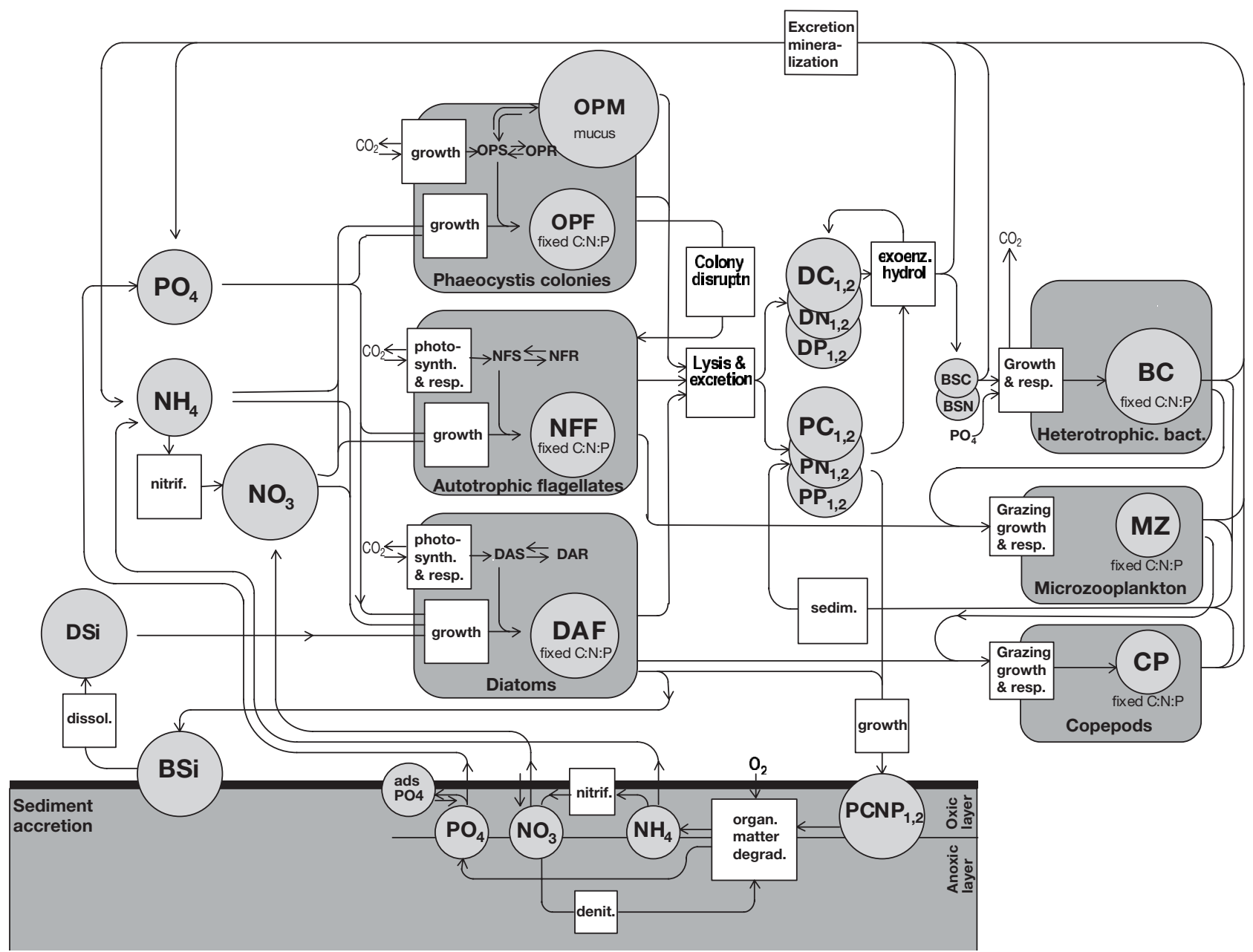

Fig. 2. Structure of the MIRO model. Diatom reserve (DAR), functional (DAF) and monomer (DAS) cell compounds; nanophytoflagellate reserve (NFR), functional (NFF) and monomers (NFS) cell compounds; Phaeocystis colony cells (OPC) and reserve (OPR), functional (OPF) and monomer (OPS) cell compounds; Phaeocystis colony matrix (OPM); other abbreviations in Table 2 
ded (Fig. 2) and which serves as a reserve of energy (Lancelot \& Mathot 1985, Veldhuis \& Admiraal 1985). Phytoplankton growth was described according to the AQUAPHY model of Lancelot et al. (1991), which considers 3 intracellular pools: monomers (S); reserve material (R, [OPM]); functional and structural metabolites $(\mathrm{F})$; the model discriminates between photosynthesis (directly dependent on light availability) and the growth process controlled by availability of intracellular monomers and ambient nutrients. A multiplication function was used for describing the light and nutrient co-limitation, where limitation by multiple nutrients was formulated using the additive parameterisation of O'Neill et al. (1989) extended to the 3 nutrients. Nutrient uptake was calculated assuming a fixed C:N:P:(Si) stoichiometry for F. Besides respiration, common loss processes included excretion and cellular lysis, the latter being a function of nutrient stress. Group-specific losses included sinking rate (for DA and OP) modulated by nutrient stress, grazing by microzooplankton (for NF) and copepods (for DA) and Phaeocystis colony disruption (for OP). The latter process was indirectly related to nutrient stress being increased by a factor 10 when OPM > OPF by a factor 1.7. Colony disruption partly resulted in formation of aggregates and partly supplied free-living cells (NF) and labile dissolved organic carbon $\left(\mathrm{DC}_{1}\right)$.

Zooplankton: The MIRO zooplankton module involved 2 groups of zooplankton: microzooplankton (MZ) feeding on autotrophic nanoflagellates (NF) and bacteria (BC), and mesozooplankton (CP) grazing on diatoms (DA) and microzooplankton (MZ). Phaeocystis colonies were not subject to grazing (Breton et al. 1999, Gasparini et al. 2000). A simplified description of zooplankton dynamics was chosen. The sigmoid (Holling III) function has been selected to express the preydependence of zooplankton grazing. Two separate parameterisations were used to describe MZ grazing on NF and $\mathrm{BC}$, since heterotrophic nanoflagellate grazing on bacteria is not detailed explicitly in the MIRO model. It is implicitly considered in the low growth efficiency coefficient attributed to $\mathrm{MZ}$ when grazing on BC (0.1) compared to NF (0.3). On the other hand, CP grazing is described by one unique HollingIII function of total prey (DA+MZ). No selective feeding (food preference) of copepods was considered due to the lack of data and the current controversy on copepod feeding (see Nejstgaard et al. 2001 and references therein). Zooplankton growth and excretion are calculated from (grazing - egestion) rates based on growth efficiency, zooplankton stoichiometry and the elemental composition of food. The model assumed thus that zooplankton excretes compounds with varying stoichiometry in order to maintain a constant body C:N:P. Second-order mortality (natural mortality and preda- tion by higher trophic levels) was considered for $\mathrm{CP}$ and constituted the MIRO closure term.

Microbial loop: The degradation of organic matter by planktonic bacteria was described according to the HSB (High polymers, Small substrates and Bacteria) model of Billen \& Servais (1989), considering 2 classes of biodegradability for DOM $\left(\mathrm{DC}_{1}, \mathrm{DN}_{1}, \mathrm{DP}_{1}\right.$ and $\mathrm{DC}_{2}$, $\left.\mathrm{DN}_{2}, \mathrm{DP}_{2}\right)$ and POM $\left(\mathrm{PC}_{1}, \mathrm{PN}_{1}, \mathrm{PP}_{1}\right.$ and $\left.\mathrm{PC}_{2}, \mathrm{PN}_{2}, \mathrm{PP}_{2}\right)$. The hydrolysis of these polymers produces dissolved monomers (BSC, BSN) that can be taken up by bacteria. The ectoenzymatic hydrolysis of DOM was described by Michaelis-Menten kinetics. The current version of MIRO uses first-order kinetics for hydrolysis of POM. The hydrolysis constant of $\mathrm{PC}_{1}, \mathrm{PN}_{1}$ and $\mathrm{PP}_{1}$ was temperature-dependent, to account for the temperature dependence of bacterial activity. According to their origin, $\mathrm{C}$ and $\mathrm{N}$ contribute in variable proportions to the pools of organic matter $\left(\mathrm{DC}_{1,2}, \mathrm{DN}_{1,2}, \mathrm{PC}_{1,2}, \mathrm{PN}_{1,2}, \mathrm{BSC}\right.$ and $\mathrm{BSN}$ ) and determine the elemental composition of organic substrates used to support bacterial growth. This proportion, compared to the bacterial $\mathrm{C}: \mathrm{N}$ ratio (assumed to be constant; Billen \& Servais 1989) determined whether net ammonification or ammonium uptake accompanied bacterial activity. All organic phosphorus $\left(\mathrm{DP}_{1,2}, \mathrm{PP}_{1,2}\right)$ was assumed to be released directly as $\mathrm{PO}_{4}$ during hydrolysis of polymeric organic matter and $\mathrm{P}$ was taken up by bacteria in its inorganic form only. $\mathrm{PO}_{4}$ uptake depended on bacterial $\mathrm{C}$ assimilation and $\mathrm{C}: \mathrm{P}$ stoichiometry. It did not depend on ambient $\mathrm{PO}_{4}$, provided its concentration is positive. With this assumption, bacteria were more competitive than phytoplankton at low $\mathrm{PO}_{4}$ concentrations.

Benthic diagenesis: Benthic organic matter degradation and nutrient $(\mathrm{N}, \mathrm{P}, \mathrm{Si})$ recycling were calculated by the algorithms developed by Lancelot \& Billen (1985) and Billen et al. (1989). These algorithms, by solving steady-state diagenetic equations expressing the mass balance of organic $\mathrm{C}$, oxygen and inorganic forms of $\mathrm{N}$ and $\mathrm{P}$ in the sedimentary column, calculate the fluxes of $\mathrm{NO}_{3}, \mathrm{NH}_{4}$ and $\mathrm{PO}_{4}$ across the sediment-water interface resulting from a given sedimentation flux of POM. The processes described included: organic matter (two classes of biodegradability) degradation, associated $\mathrm{NH}_{4}$ and $\mathrm{PO}_{4}$ release, $\mathrm{O}_{2}$ consumption, nitrification and denitrification, $\mathrm{PO}_{4}$ and $\mathrm{NH}_{4}$ adsorption onto organic material, mixing in the interstitial and solid phases, and accretion of the sedimentary column by inorganic matter sedimentation (Fig. 2). First-order kinetics described biogenic silica (BSi) dissolution and release of DSi to the water column.

Model parameterisation. Parameters and forcing functions (Table 1, Appendix 5; www.int-res.com/ journals/suppl/appendix_lancelot.pdf) were estimated based on independent targeted process-level studies performed under field and/or laboratory conditions over 
the last $20 \mathrm{yr}$, and on a review of literature on Phaeocystis ecology and physiology (Schoemann et al. 2004). Due to the large number of parameters, we defined the set of parameters to which the model results are the most sensitive. For this purpose several approaches can be taken. For instance, the effect of a given parameter on the model results could be assessed by increasing or decreasing the value of each parameter and by calculating a normalized sensitivity factor that measures the fractional change in a given model component compared to a fractional change in the parameter of interest (Fasham et al. 1993, Friedrichs \& Hofmann 2001). Given the large number of parameters and variables in MIRO, we opted for the variational adjoint method described in Lawson et al. (1995) and Spitz et al. $(1998,2001)$ and an identical twin experiment using model-generated data. Since the model was consistent with the data and no noise was added to the data set, the order in which the model parameters were recovered and the corresponding magnitude of the decrease of the cost function allowed an estimate of the sensitivity of the model results to a given parameter. In addition, use of data assimilation and observations at Stn 330 indicated critical pathways that were missing from an earlier version of the model (Lancelot et al. 1997) and required re-analysis of current knowledge and observations. For example, it was found necessary for the Phaeocystis colonies to have a lysis coefficient that varies with time, as well as a seasonally varying $\mathrm{Si}$ : C ratio for the diatoms, consistent with the observations of Rousseau et al. (2002). The results of data assimilation with the present model and of the observations at Stn 330 are the subject of a forthcoming study (Spitz unpubl.).

Model runs. For the application of the MIRO model to the continental coastal waters of the North Sea, a multi-box frame was constructed based upon the hydrological regime. This coarse resolution of the hydrodynamics represents a first approach to this tidally wellmixed area. To account for the cumulative nutrient enrichment of Atlantic waters by the Seine and Scheldt rivers, 2 successive boxes (FCZ, BCZ), assumed to be homogeneous, represent the coastal strip from the Bay of the Seine to the Scheldt estuary (see Fig. 1). The offshore limit of the boxes runs along a residual streamline, so that inshore-offshore exchanges by residual advection can be neglected. Each box has its own characteristics (Table 1) and is treated as an open system, receiving waters from the adjacent box to the SW and exporting water to the one located to the NE. The sea- sonal variation of the state variables was calculated by solving the equations expressing mass conservation in the system with an Eulerian time discretisation of 15 min. Experiments with smaller time steps as well as a Runge-Kutta scheme have been performed and showed that such a time step is appropriate and does not lead to mathematical instability. Climatological functions calculated from the period 1989 to 1999 (Table 1) were used for meteorological and nutrient input forcing. These functions were parameterised from recorded daily solar global radiation (meteorological station Oostende, Institut Royal Météorologique), seawater temperature and monthly nutrient loads for the rivers Seine (Cellule Antipollution de Rouen du Service de la Navigation de la Seine, France) and Scheldt (Institute for Inland Water Management and Waste Water Treatment-RIZA, The Netherlands, and Department of Environment and Infrastructure, Ministry of the Flemish Community, Belgium). Monthly river nutrient load data were interpolated and directly mixed at each time step in the relevant boxes.

SW boundary conditions were provided by the results of MIRO calculations performed for the conditions existing in the western Channel area $\left(\mathrm{WCH}_{\text {; }}\right.$ considered as a quasi-oceanic closed system), using initial values reported in Table 2. Initial conditions of nutrients and phytoplankton were extracted from the climatological data base of Radach et al. (1995). For these boundary conditions, sediment processes are not taken into account and model runs are performed for meteorological conditions of 1989 until a steady state is reached. This occurs after 3 yr. 
Table 2. MIRO model: initial conditions (after Radach et al. 1995)

\begin{tabular}{|c|c|c|}
\hline State variable & Description & Value \\
\hline $\mathrm{NO}_{3}$ & Nitrate & $8.7 \mathrm{mmol} \mathrm{m}^{-3}$ \\
\hline $\mathrm{NH}_{4}$ & Ammonia & $2 \mathrm{mmol} \mathrm{m}^{-3}$ \\
\hline $\mathrm{PO}_{4}$ & Phosphate & $0.5 \mathrm{mmol} \mathrm{m}^{-3}$ \\
\hline DSi & Dissolved silica & $6 \mathrm{mmol} \mathrm{m}^{-3}$ \\
\hline DA & Diatom biomass & $2 \mathrm{mgC} \mathrm{m}^{-3}$ \\
\hline NF & Nanophytoflagellate biomass & $2 \mathrm{mgC} \mathrm{m}^{-3}$ \\
\hline $\mathrm{OP}$ & Phaeocystis colony biomass & $0.001 \mathrm{mgC} \mathrm{m}^{-3}$ \\
\hline $\mathrm{BC}$ & Bacterial biomass & $1 \mathrm{mgC} \mathrm{m}^{-3}$ \\
\hline $\mathrm{MZ}+\mathrm{CP}$ & Microzooplankton and copepod biomass & $1.5 \mathrm{mgC} \mathrm{m}^{-3}$ \\
\hline BSC & Bacteria-available carbon monomeric substrates & $5 \mathrm{mgC} \mathrm{m}^{-3}$ \\
\hline $\mathrm{DC}_{1}+\mathrm{DC}_{2}+\mathrm{PC}_{1}+\mathrm{PC}_{2}$ & $\begin{array}{l}\text { Dissolved and particulate organic carbon of high (1) and } \\
\text { low (2) biodegradability }\end{array}$ & $620 \mathrm{mgC} \mathrm{m}^{-3}$ \\
\hline BSN & Bacteria-available nitrogen monomeric substrates & $0.05 \mathrm{mmol} \mathrm{m}^{-3}$ \\
\hline $\mathrm{DN}_{1}+\mathrm{DN}_{2}+\mathrm{PN}_{1}+\mathrm{PN}_{2}$ & $\begin{array}{l}\text { Dissolved and particulate organic nitrogen of high (1) and } \\
\text { low (2) biodegradability }\end{array}$ & $6.2 \mathrm{mmol} \mathrm{m}^{-3}$ \\
\hline $\mathrm{DP}_{1}+\mathrm{DP}_{2}+\mathrm{PP}_{1}+\mathrm{PP}_{2}$ & $\begin{array}{l}\text { Dissolved and particulate organic phosphorus of high (1) and } \\
\text { low (2) biodegradability }\end{array}$ & $0.31 \mathrm{mmol} \mathrm{m}^{-3}$ \\
\hline BSi & Biogenic silica & $3 \mathrm{mmol} \mathrm{m}^{-3}$ \\
\hline
\end{tabular}

Validation data. Biogeochemical data sets for model validation were obtained from existing time series at 3 reference stations in $\mathrm{WCH}\left(48^{\circ} 43.30^{\prime} \mathrm{N}, 03^{\circ} 50^{\prime} \mathrm{W}\right)$, FCZ: $50^{\circ} 44.5^{\prime} \mathrm{N}, 01^{\circ} 30.8^{\prime} \mathrm{E}$ ) and BCZ (Stn 330: $51^{\circ} 26.05^{\prime} \mathrm{N}, 002^{\circ} 48.50^{\prime} \mathrm{E}$ ) (see Fig. 1). The WCH and FCZ data sets are limited to the 1989-1993 period (Lancelot et al. 1994) and include temperature, nutrients and phytoplankton data (chl a, diatoms and Phaeocystis). For the BCZ a better time series and state variable resolution is available, since Stn 330 was set up for monitoring the seasonal and interannual variations of algal blooms and related parameters. Data include temperature, nutrients, DOC, phytoplankton, bacteria, and micro- and mesozooplankton sampled at weekly or 2 wk intervals between 1989 and 2000 (Lancelot et al. 2004). For this comparison, predicted chl a was calculated by summing predictions of DAF, NFF and OPF and using a C:chl a factor of 0.04 (mg:mg; after Lancelot-Van Beveren 1980). Colonial cell biomass (OPF + OPS + OPR) was converted to Phaeocystis cells assuming a carbon content of $14 \mathrm{pg} \mathrm{cell}^{-1}$ (Rousseau et al. 1990).

\section{RESULTS}

\section{Seasonal features of nutrients and phytoplankton blooms along the SW-NE gradient}

The current capability of MIRO to reproduce the observed SW-NE nutrient enrichment gradient and the related spreading of phytoplankton blooms in spring is shown in Figs. 3 \& 4, which compare the climatological seasonal cycle of nutrients (Fig. 3) and phytoplankton (Fig. 4) simulated by MIRO runs in the successive boxes WCH, FCZ and BCZ with 5 d average data collected over the simulated period at the corresponding reference stations. The model draws fairly well the cumulated SW-NE enrichment shown in all nutrients by the 3-fold $\left(\mathrm{DSi}, \mathrm{PO}_{4}\right)$ to 4 -fold $\left(\mathrm{NO}_{3}\right)$ increase of winter concentrations in BCZ (Fig. 3a-C), compared to the winter signature of Atlantic waters (WCH; Fig. 3g-i). One exception is the MIRO overestimation of winter $\mathrm{PO}_{4}$ in Atlantic waters (Fig. 3i). This may be explained by the lack of consideration of $\mathrm{P}$ retention in the sediment of box WCH. This overestimation, however, does not bias nutrient simulations in the FCZ (Fig. 3f) and BCZ (Fig. 3c). The timing and magnitude of spring nutrient decrease (Fig. 3) is well represented by the model and corresponds with phytoplankton development in spring (Fig. 4). The spring maximum chl a simulated in each box corresponds reasonably well to observed average concentrations for the simulated 1989 to 1999 period and shows a 4 -fold increase along the SW-NE gradient (Fig. 4a,c,e). These maxima coincide with Phaeocystis blooms (Fig. 4b,d), except in the WCH, where no Phaeocystis colony bloom is shown by the model, in agreement with previous monitoring studies (Sournia et al. 1987). The modelled Phaeocystis cell abundance in FCZ and $\mathrm{BCZ}$ reproduces quite well the observed onset time and duration of blooms, but exceeds the highest 
recorded concentrations (Fig. 4b,d). Less well described in the BCZ are the summer nutrient decreases (Fig. 3a-c) and phytoplankton blooms (Fig. 4a). The simultaneous MIRO underestimation of summer and fall chl a (Fig. 4a) and overestimation of nutrients (Fig. 3a-c, Fig. 5g) suggest that the dynamics of summer blooms is less well represented by the model than the spring bloom.

\section{Seasonal distribution of auto- and heterotrophic biomasses and related biogeochemical variables in the $\mathrm{BCZ}$}

The ability of MIRO to describe the dynamics of Phaeocystis-dominated ecosystems is shown in Fig. 5. The main ecological trends (seasonal succession of auto- and heterotrophic microorganisms, order of mag- nitude of biomass reached) and related nutrient cycles (Fig. 3a-c) are reasonably well simulated, considering the complexity of the ecosystem and the simplified physics used here. Particularly well modelled are the spring-summer phytoplankton successions with Phaeocystis colonies and nanophytoflagellate blooms between spring and summer diatom blooms (Fig. 5a-c). However, the model results obtained for summer correspond to the lower range of observed summer-fall diatom biomasses (Fig. 5a), as already shown for chl a results (Fig. 4a); the model does not reproduce the summer minimum observed for all nutrients around Day 230 (Fig. 3a-c, Fig. 5g). The observed maxima of copepod biomass in late spring (Days 140 to 180; Fig. 5d) are not captured by the model and may result from imperfectly simulated dynamics of copepod prey (Fig. 5a,e). As a consequence, in our simulations the spring diatoms are not heavily controlled by cope-
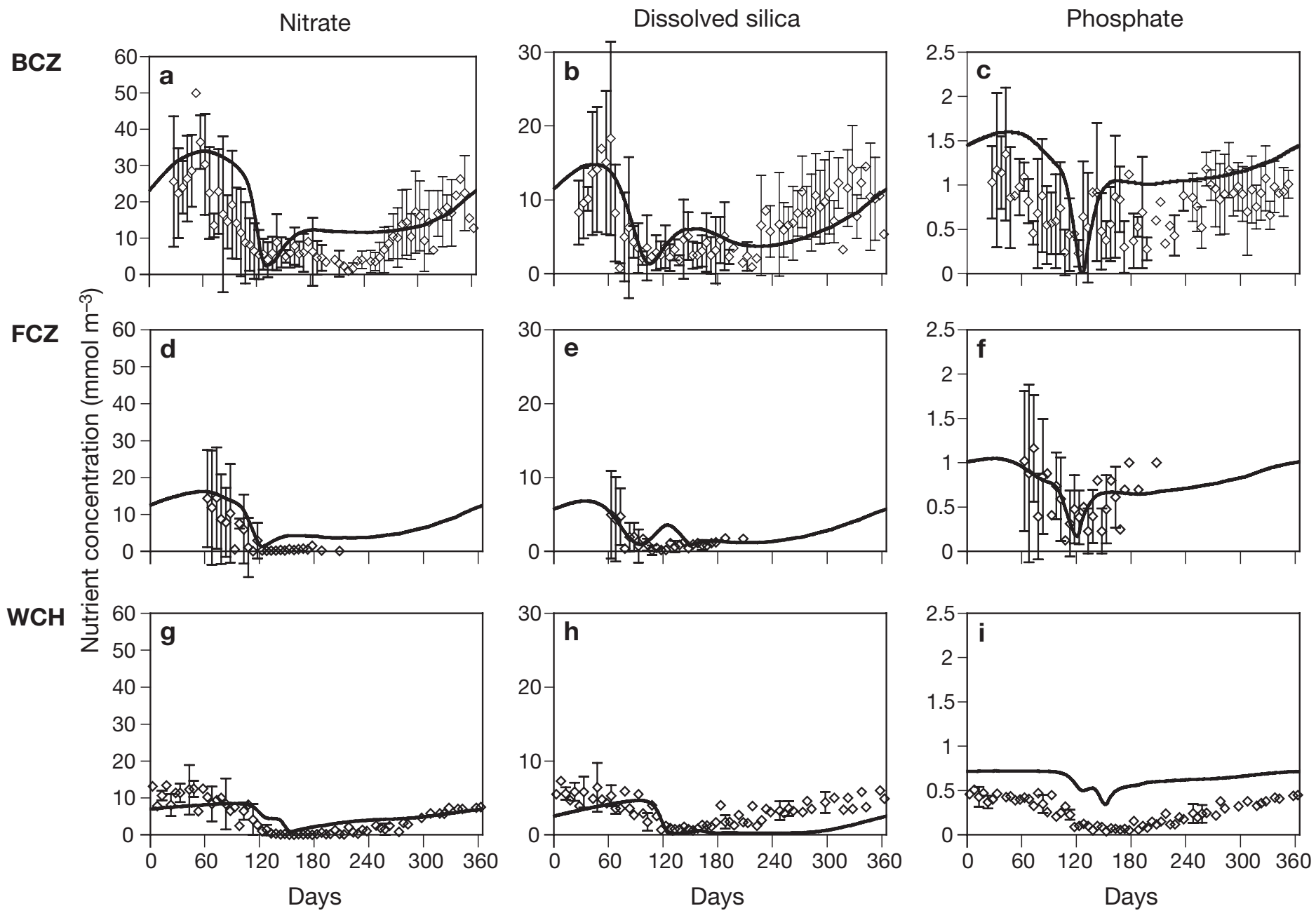

$\diamond$ Observations (5 d average)

- MIRO results

Fig. 3. MIRO results (climatological run) and 1989-1999 observations (5 d mean \pm SD) for nutrients at the 3 monitoring stations

(Fig. 1) along the SW-NE gradient 

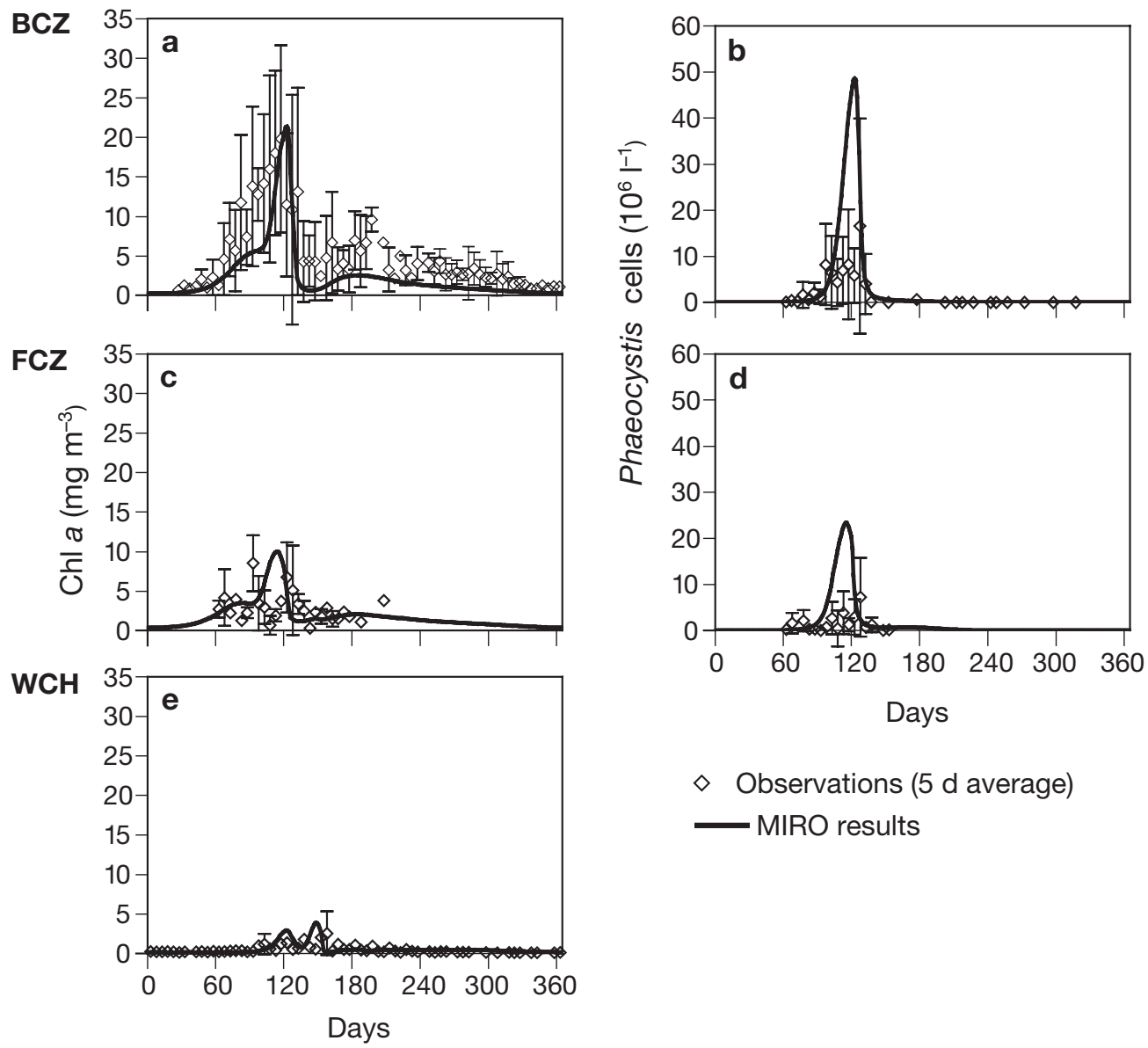
$\diamond$ Observations (5 d average)
MIRO results

Fig. 4. MIRO results (climatological run) and 1989-1999 observations (5 d mean \pm SD) for phytoplankton at 3 monitoring stations

(Fig. 1) along the SW-NE gradient

pod grazing and most of the spring diatom decrease after Day 90 is explained by sinking and lysis. The latter process releases labile $\mathrm{DOC}$, i.e. $\mathrm{DC}_{1}+\mathrm{DC}_{2}$ (Fig. 5h), which stimulates an early development of bacteria at the decline of the diatom bloom (Fig. 5a,f). The simulated magnitude of the bacterial biomass is, however, significantly higher than observed at that time (Day 115; Fig. 5f), probably due to the delay in growth of model microzooplankton (Fig. 5e,f). In agreement with observations, our simulations show that the diatom decline at Day 105 corresponds to the lowest DSi concentration (Fig. 3b). Phaeocystis colony decline at Day 126 (Fig. 5c) is associated with $\mathrm{PO}_{4}$ depletion (Fig. 3c), but $\mathrm{NO}_{3}$ minima are simulated some 5 d later (Fig. 3a). As a consequence, elevated $\mathrm{N}$ :P ratios (between 50 and 900, not shown) are simulated over the Phaeocystis bloom period compared to winter ( 20 to 25 , not shown). Similar trends are observed for field N:P ratios, which range in spring between 50 and 320 (not shown). The Phaeocystis colony decay releases labile DOC and free-living cells, both showing maximal concentrations at Day 129
(Fig. 5b,h). The liberated cells add up ambient nanophytoflagellates and stimulate microzooplankton growth, which responds to this sudden prey supply with a delay of $3 \mathrm{~d}$ (Fig. 5e). Microzooplankton in turn reduces bacterial biomass (Fig. 5f), causing a transient accumulation of labile DOC up to Day 180 (Fig. 5h). In agreement with observations, significant nutrient increases (mostly $\mathrm{NH}_{4}$ and $\mathrm{PO}_{4}$; Figs. 3c \& 5g) are simulated between Days 125 and 145 and coincide with microzooplankton and bacterioplankton blooms (Fig. 5e,f).

\section{Spring $\mathrm{C}$ budget and trophic efficiency}

MIRO competence was also evaluated by estimations of flow rate-based budgets performed in spring 1998 for the central BCZ (Rousseau et al. 2000). A spring budget of carbon flow through the planktonic network and to the sediment was constructed for $\mathrm{BCZ}$, based on time integration over the diatomPhaeocystis bloom period (Days 50 to 150) of MIRO 
Diatom

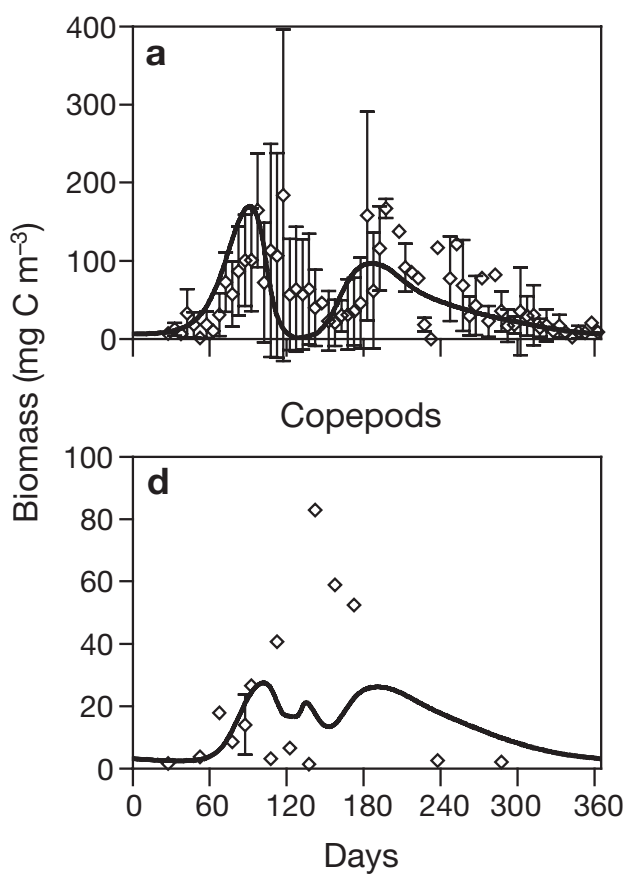

Nanophyto

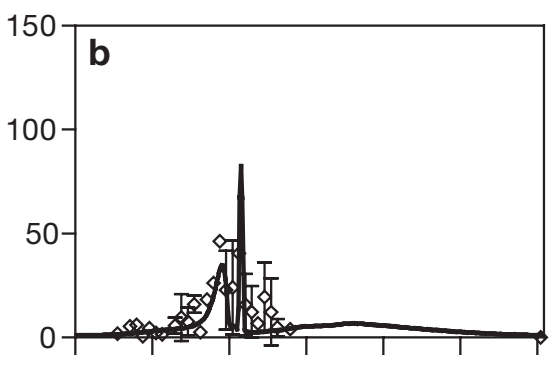

Microzoo

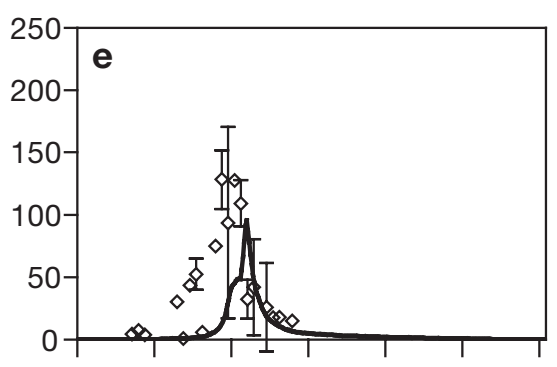

Ammonia $\left(\mathrm{mmol} \mathrm{m}^{-3}\right)$

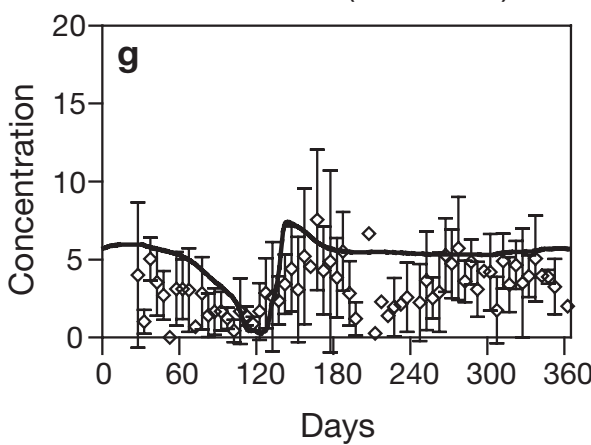

Phaeocystis colony

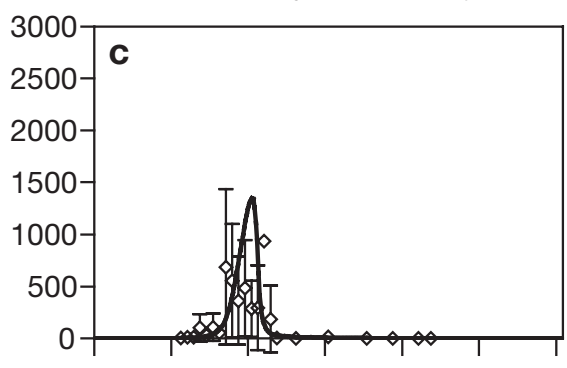

Bacteria

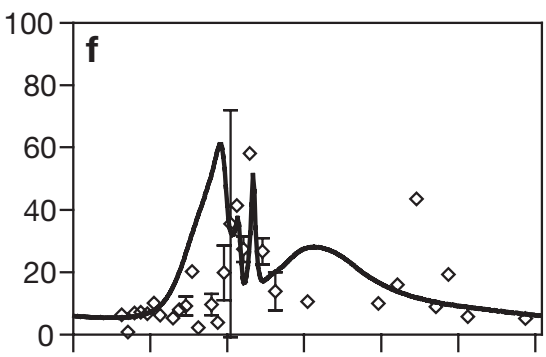

Labile DOC $\left(\mathrm{mg} \mathrm{C} \mathrm{m}^{-3}\right)$

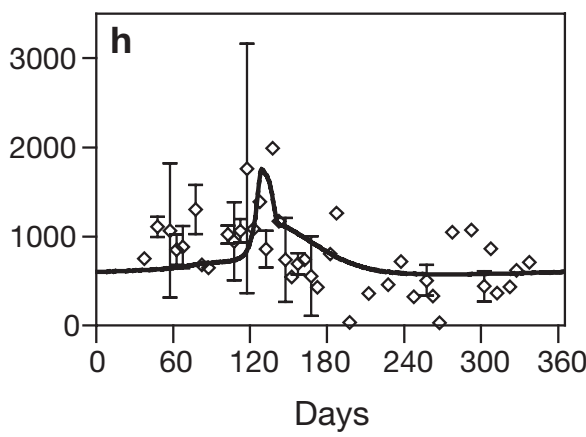

Fig. 5. MIRO results (climatological run) in the Belgian coastal zone (Stn 330), and 1989-1999 observations (5 d mean \pm SD) of auto- and heterotrophic biomasses and related biogeochemical variables

daily simulations of biological activities obtained with actual 1998 forcing by incident PAR and river nutrient loads. Results of these calculations (Table 3) are compared with similar estimates calculated by integration of field planktonic process rates measured twice monthly in spring 1998 at Stn 330 (Rousseau et al. 2000; Table 3). When constrained with 1998 forcing, MIRO estimates total gross primary production (GPP) in spring at $153 \mathrm{gC} \mathrm{m}^{-2}$, i.e. $26 \%$ higher than that based on field measurements (Table 3). This difference arises mainly because $80 \%$ of field measurements were performed during exceptionally cloudy days (Rousseau et al. 2000), i.e. global solar irradiance was $15 \%$ less than the corresponding $10 \mathrm{~d}$ average (not shown). For net primary production (NPP), a difference is also observed, which is even higher due to the lower algal respiration rate calcu- lated by MIRO compared to the 1998 estimates (Table 3). On the other hand, the observed and modelled share of NPP between the 3 phytoplankton groups (diatoms, Phaeocystis, nanoflagellates) is remarkably similar, with Phaeocystis colonies contributing 70 to $77 \%$ of NPP in spring (Table 3). The largest discrepancy between model results and observations relates to the fate of Phaeocystis production. While Rousseau et al. (2000) concluded that most of the 1998 spring NPP autolyses and flows through planktonic bacteria, MIRO estimates that some $14 \%$ of the spring NPP reaches the sediment as sinking cells and phytoplankton-derived detritus (Table 3). Such a difference is partly reflected in the modelled bacterioplankton growth $(40 \%$ lower than that deduced from twice monthly measurements; Table 3), and trophic interactions between organisms forming the microbial 
network. Indeed, a larger part of MIRO bacterial production feeds microzooplankton, for which model grazing on bacteria is $120 \%$ higher than estimated from field heterotrophic nanoflagellate biomass (Rousseau et al. 2000). As a consequence, simulated copepod grazing on microzooplankton in spring is $100 \%$ higher than observed (Table 3). On the other hand, field estimates and MIRO estimates of microzooplankton grazing on nanoflagellates agree reasonably well, and both show the importance of autotrophic nanoflagellates over bacteria as a prey for microzooplankton (Table 3). Nevertheless, the differences between observed and modelled bacterial growth and fate have little impact on the global trophic efficiency of the microbial network. This corresponds to the ratio between copepod grazing on microzooplankton and the resource inflow, i.e. the supply of organic C and the NPP of autotrophic nanoflagellates (Table 3 ), and is estimated at only $2 \%$ (field observations) and $3 \%$ (MIRO results). In comparison, the trophic efficiencies of the diatom-tocopepod food chain (the ratio between copepod grazing on diatoms and diatom NPP; Table 3) are higher and similar (34 and 36\% based on field observations and MIRO estimates, respectively).

Table 3. Spring and annual carbon budget $\left(\mathrm{gC} \mathrm{m}^{-2}\right)$ based on MIRO predictions of plankton biological activity in the Belgian coastal zone (BCZ). Comparison with the spring budget calculated from 1998 measurements of planktonic carbon flows (Rousseau et al. 2000)

\begin{tabular}{|c|c|c|c|c|}
\hline \multirow[t]{2}{*}{ Plankton activity } & \multicolumn{2}{|c|}{ Spring 1998} & \multicolumn{2}{|c|}{ MIRO budget 1989 to 1999} \\
\hline & Field & MIRO & Spring & Annual \\
\hline Gross primary production & 121 & 153 & 181 & 258 \\
\hline Net primary production & 97 & 134 & 155 & 213 \\
\hline Diatoms & 16 & 14 & 25 & 74 \\
\hline Phaeocystis colonies & 68 & 103 & 113 & 117 \\
\hline Nanoflagellates & 13 & 17 & 17 & 22 \\
\hline Copepod grazing & 7 & 9 & 13 & 39 \\
\hline On diatoms & 5 & 5 & 9 & 33 \\
\hline On microzooplankton & 2 & 4 & 4 & 6 \\
\hline Microzooplankton grazing & 17 & 25 & 26 & 32 \\
\hline On bacteria & 5 & 11 & 12 & 14 \\
\hline On nanoflagellates & 12 & 14 & 14 & 18 \\
\hline Microbial loop & & 221 & 257 & 359 \\
\hline Organic C supply & & 104 & 120 & 167 \\
\hline Autotrophs & & 87 & 103 & 127 \\
\hline Heterotrophs & & 17 & 18 & 40 \\
\hline Bacterial growth & 32 & 13 & 16 & 25 \\
\hline Sedimentation & & 19 & 25 & 51 \\
\hline Diatom & & 2 & 3 & 8 \\
\hline Phaeocystis colonies & & 9 & 12 & 33 \\
\hline Detritus & & 8 & 10 & 10 \\
\hline \multicolumn{5}{|l|}{ Balance } \\
\hline Inflow & & & & 126 \\
\hline Outflow & & & & 138 \\
\hline
\end{tabular}

\section{DISCUSSION}

\section{Prediction capability of MIRO: success, caveats and perspectives}

To our knowledge, MIRO is the first biogeochemical model that describes the cycling of $\mathrm{C}$ and nutrients $(\mathrm{N}$, $\mathrm{P}, \mathrm{Si}$ ) in the planktonic and sediment component of the diatom/Phaeocystis-dominated ecosystem of the North Sea over the entire season. It is also the first model that fully considers the 2 main Phaeocystis stages (freeliving cells and colonies), as well as their interrelations, trophic fates and associated carbon and nutrient fluxes. The Phaeocystis module is, however, simple, compared to the individual-based conceptual model of Canziani \& Hallam (1996), which explicitly describes the different Phaeocystis life forms, 2 classes of colony sizes defined according to their palatability, and their interactions with 3 grazers. Such a detailed size distribution of Phaeocystis colonies is not necessary in the ecosystem investigated here, as no trace of Phaeocystis colonies was recorded in the gut content of copepods during spring blooms (Breton et al. 1999, Gasparini et al. 2000). Nevertheless, additional MIRO sensitivity tests allowing copepods to graze only on the small colonies (diameter $<400 \mu \mathrm{m}$ ) had no significant impact on Phaeocystis colony bloom development (Fig. 6b), although copepod biomass increased by $15 \%$ by Day 120 (Fig. 6c). For this model run, small colonies were determined on the basis of their lower $\mathrm{C}$ colony matrix-to-cell ratio (OPM:OPF), compared to large colonies, and a threshold of 0.8 was chosen from Rousseau et al. (1990).

The model of Verity (2000) for describing trophic interactions associated with Phaeocystis pouchetii growth in mesocosms also distinguishes the 2 life forms. However, although it is relevant for testing trophic interactions, this Nbased model has no explicit description of the mucilaginous matrix of Phaeocystis colonies, which is composed mainly of polysaccharidic carbon. Such a model structure therefore fails to address the crucial role of Phaeocystis colonies in determining the functioning of the ecosystem and related environmental impacts due to foam accumulations (Lancelot et al. 1994, Lancelot 1995). Moreover, by lacking an explicit description of the $\mathrm{P}$ cycling, Verity's model cannot be applied to eutrophi- 

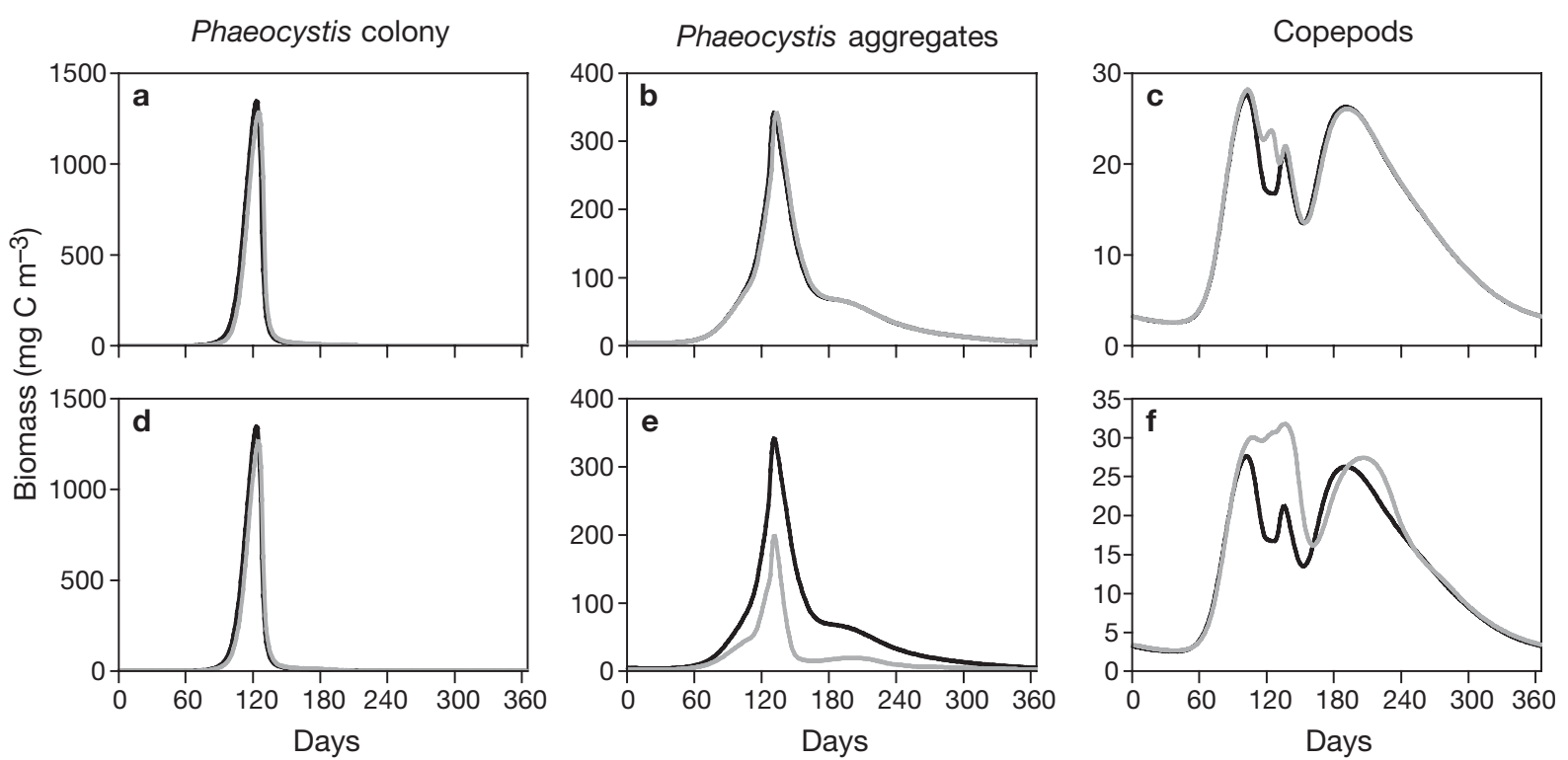

Fig. 6. MIRO sensitivity tests with varying copepod prey. Comparison between predictions of Phaeocystis colonies (a,d), Phaeocystis-derived aggregates $(\mathrm{b}, \mathrm{e})$ and copepod biomass $(\mathrm{c}, \mathrm{f})$ obtained for different prey: diatoms and microzooplankton (reference, black line), similar + small colonies (grey line, a-c), similar + Phaeocystis-derived aggregates (grey line, $d-f$ )

cated coastal waters, where nutrient N:P ratios are far from Redfield cell stoichiometry (Redfield et al. 1963) due to the changing supply of anthropogenic nutrients. Clearly, MIRO application in the Eastern Channel and Southern Bight of the North Sea identifies the key role of Phaeocystis affinity for low $\mathrm{PO}_{4}$ in determining the success and magnitude of Phaeocystis blooms along the $\mathrm{NO}_{3}$ rich coastal zone (Figs. 3c \& 5c), as already suggested from field observations (Veldhuis \& Admiraal 1987, Veldhuis et al. 1991).

This first application of the multi-box MIRO in the Southern Bight of the North Sea shows that the model built on current knowledge of Phaeocystis ecophysiology and trophic interactions is able to describe the increase in Phaeocystis blooms and the related nutrient decreases observed in spring along the coastal zone in a SW-NE gradient (Figs. 3 to 5). Particularly well simulated are the diatom-Phaeocystis succession and their biomass production, as well as the succession of Phaeocystis colonies to nanophytoflagellates (including free-living Phaeocystis cells) (Fig. 5). As observed in the field (Veldhuis et al. 1986, Rousseau et al. 2000), the sudden spring increase of nanophytoflagellates predicted at colony decline results from the transient accumulation of active free-living Phaeocystis cells released in the water column after colony disruption. In MIRO, the latter process is included after microscopy observations of colony growth development and $\mathrm{C}$ distribution between colonial cells and matrix (Rousseau et al. 1990) and is described as a threshold function of the $\mathrm{C}$ matrix-to-cell ratio (OPM:OPF) in colonies, adjusted on the basis of several model sensi- tivity runs. Further process-level studies are needed to investigate the physiological basis of Phaeocystis colony senescence and disruption, for which control factors are poorly known (e.g. Rousseau et al. 1994, Schoemann et al. 2005).

The distribution of cells and compounds issued from disrupted Phaeocystis colonies between nanophytoflagellates (Phaeocystis free-living cells), DC1 (Phaeocystis matrix) and PC1 (Phaeocystis-derived aggregates) is arbitrary but important in our model. The latter constitutes the most efficient vector for transporting Phaeocystis-derived matter to the North Sea sediment (e.g. Riebesell 1993). Hence, the appropriate sharing of Phaeocystis colony-derived matter between cells and DC1 and PC1 is of prime importance for assessing the trophic efficiency of Phaeocystis-dominated ecosystems and localizing the preferential site (sediment vs water column) of microbial degradation of Phaeocystis-derived matter and the associated nutrient regeneration processes. The significance of aggregation and sedimentation for the termination of Phaeocystis colony blooms in coastal waters of the North Sea is still unclear. Planktonic carbon budget calculations over the vegetative period show that Phaeocystis sedimentation should be of little significance in such a shallow coastal sea (Brussaard et al. 1995, Rousseau et al. 2000). This is challenged by observed transient accumulations of colonies on the sediment (Riebesell 1993, Cadée 1996, Peperzak et al. 1998) as well as indirect evidence of fresh POM deposited on the seabed during the decline of a Phaeocystis bloom (Schoemann et al. 1998). The ability of Phaeocystis to change colony 
density with varying nutrient and light conditions in combination with local hydrodynamics (Peperzak et al. 2003) might explain this apparent contradiction.

Improving the knowledge of processes regulating the planktonic and sediment fate of ungrazed Phaeocystis colonies is of prime importance, as this will determine the rate at which nutrients are regenerated and available for sustaining the growth of summer diatoms and mesozooplankton. In this respect it is important to note a weakness of MIRO in simulating accurately the magnitude of the observed postPhaeocystis diatom bloom and the associated decrease in $\mathrm{NO}_{3}, \mathrm{NH}_{4}$ and $\mathrm{PO}_{4}$ (Figs. 3 \& 5). The predicted summer nutrient accumulation results from an imbalance between fast nutrient regeneration and/or underestimation of nutrient consumption by summer diatoms. Solving this question requires that process-level experiments be carried out to improve MIRO parameterisation of growth physiology and nutrient uptake in diatoms during summer. Also not well represented in MIRO simulations is the seasonal evolution of copepod biomass (Fig. 5d). This seems to be due to a mismatch between the simulated seasonal succession of copepods and prey (Fig. 5d,a,e). The predicted spring decrease of copepod biomass after Day 105 (Fig. 5d) corresponds to an absence of prey, due to an early decline in diatom biomass (Fig. 5a), a delayed development of microzooplankton (Fig. 5e), or lack of consideration of copepod grazing on phytoplankton-derived detrital matter. Improving the MIRO description of these processes requires more experimental work on copepod diets and food preferences, and improvement of the model's feeding function. Of particular interest is the regulation of microzooplankton feeding on bacteria and the copepods' ability to feed on Phaeocystis derived matter (Estep et al. 1990). The latter was explored by performing additional MIRO sensitivity tests, where Phaeocystis-derived matter was added as food for copepods (Fig. 6). For this simulation we assumed that only the highly biodegradable $\left(\mathrm{PC}_{1}, \mathrm{PN}_{1}\right.$, $\mathrm{PP}_{1}$ ) fraction of Phaeocystis-derived aggregates was palatable for copepods. Comparison with the reference run (Fig. 6d-f) shows some improvement of the copepod biomass description in late spring, but the observed maximum of 60 to $80 \mathrm{mgC} \mathrm{m}^{-3}$ is not simulated by the model.

\section{Annual carbon budget and nutrient retention in the BCZ}

Carbon budget

Daily simulations of carbon and nutrient fluxes were used to assess annual carbon (Table 3) and nutrient cycling (Fig. 7) in the BCZ for 1989 to 1999. MIRO estimated annual GPP at $258 \mathrm{gC} \mathrm{m}^{-2}$. Some $17 \%$ is lost by phytoplankton respiration, giving $213 \mathrm{gC} \mathrm{m}^{-2}$ for the average annual NPP. This figure is slightly higher than a field estimate of particulate NPP made by Joiris et al. (1982) for 1971 to $1980\left(170 \mathrm{gC} \mathrm{m}^{-2}\right)$, but it is significantly lower (by $33 \%$ ) when their estimate of dissolved NPP is added (150 $\mathrm{gC} \mathrm{m}^{-2}$; Joiris et al. 1982). Such an estimate of phytoplankton excretion is extremely high compared to the MIRO estimate $\left(5 \mathrm{gC} \mathrm{m}^{-2} \mathrm{yr}^{-1}\right.$; Table 3). In 1982, however, no distinction was made between diatom and Phaeocystis primary production and the carbon metabolism of the Phaeocystis colony matrix (Lancelot \& Mathot 1985) was unknown. Therefore the method probably led to a significant overestimation of the dissolved NPP, including some contribution of Phaeocystis mucus. On the other hand, the C budget period of Joiris et al. (1982) corresponds to years when $\mathrm{N}$ and $\mathrm{P}$ Scheldt loads were maximal, and greatly in excess with respect to $\mathrm{Si}$ requirements of diatoms (Billen et al. 2005), suggesting that primary production was higher and had a larger contribution by Phaeocystis colonies (and therefore mucus production), compared to the MIRO simulations for the last decade. Finally, meteorological conditions, which modulate global solar radiation and nutrient loads, could also explain the difference in primary production between years, as suggested from the comparison of spring primary production between 1998 and the climatological year (Table 3).

Based on MIRO predictions, diatoms (35\%) and Phaeocystis (55\%) contribute up to $90 \%$ of annual NPP. The spring bloom produces $73 \%$ of the annual NPP, with Phaeocystis as the dominant contributor. This figure might be an overestimate due to some weakness of MIRO in describing biomass reached during the summer-autumn period. The spring and summer blooms supply 34 and $66 \%$ of annual diatom production, respectively. Despite the high annual primary production, MIRO estimates the trophic efficiency of the BCZ planktonic system as modest (less than $20 \%$; Table 3 ) due to the low efficiency of the microbial network $(3 \%)$ compared to the linear diatom-to-copepod food chain $(45 \%)$. On an annual basis some $80 \%$ of the NPP is not grazed by copepods and flows through the microbial network; $88 \%$ of this enters the bacterial loop (Table 3). These results are similar to estimates by Joiris et al. (1982), although these authors do not have an accurate description of the mechanisms that supply DOM to bacteria. In addition, MIRO estimates that only $20 \%$ of ungrazed primary production is deposited on the sediment, partly as sinking phytoplankton and partly as derived aggregates (Table 3 ). The MIRO annual estimate of overall carbon input to the sediment (51 $\mathrm{gC} \mathrm{m}^{-2}$; Table 3) is comparable to a 2003 estimate 
(a) Nitrogen (gN m$\left.{ }^{-2} \mathrm{yr}^{-1}\right)$

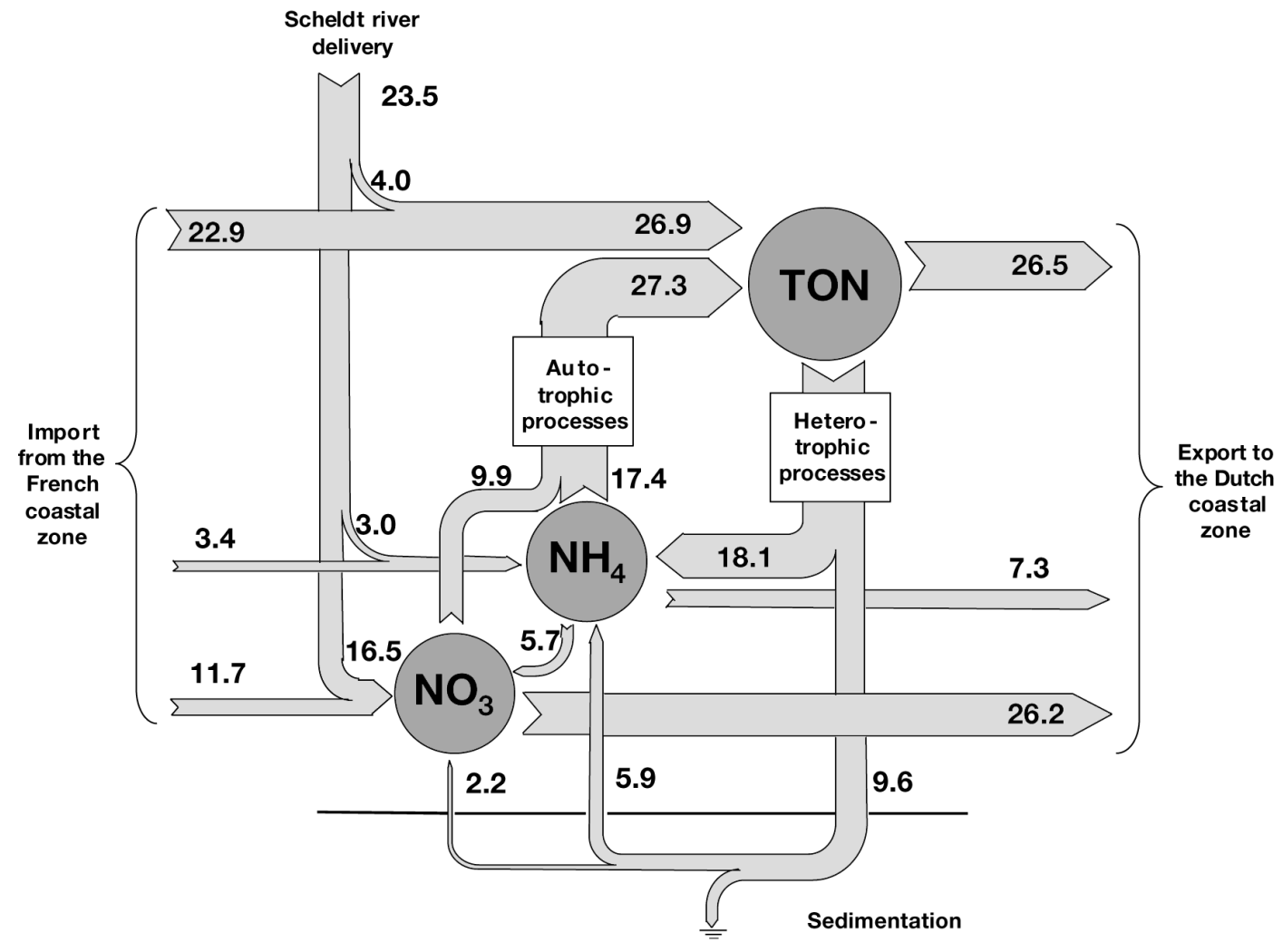

(b) Phosphorus $\left(\mathrm{g} \mathrm{m}^{-2} \mathrm{yr}^{-1}\right)$

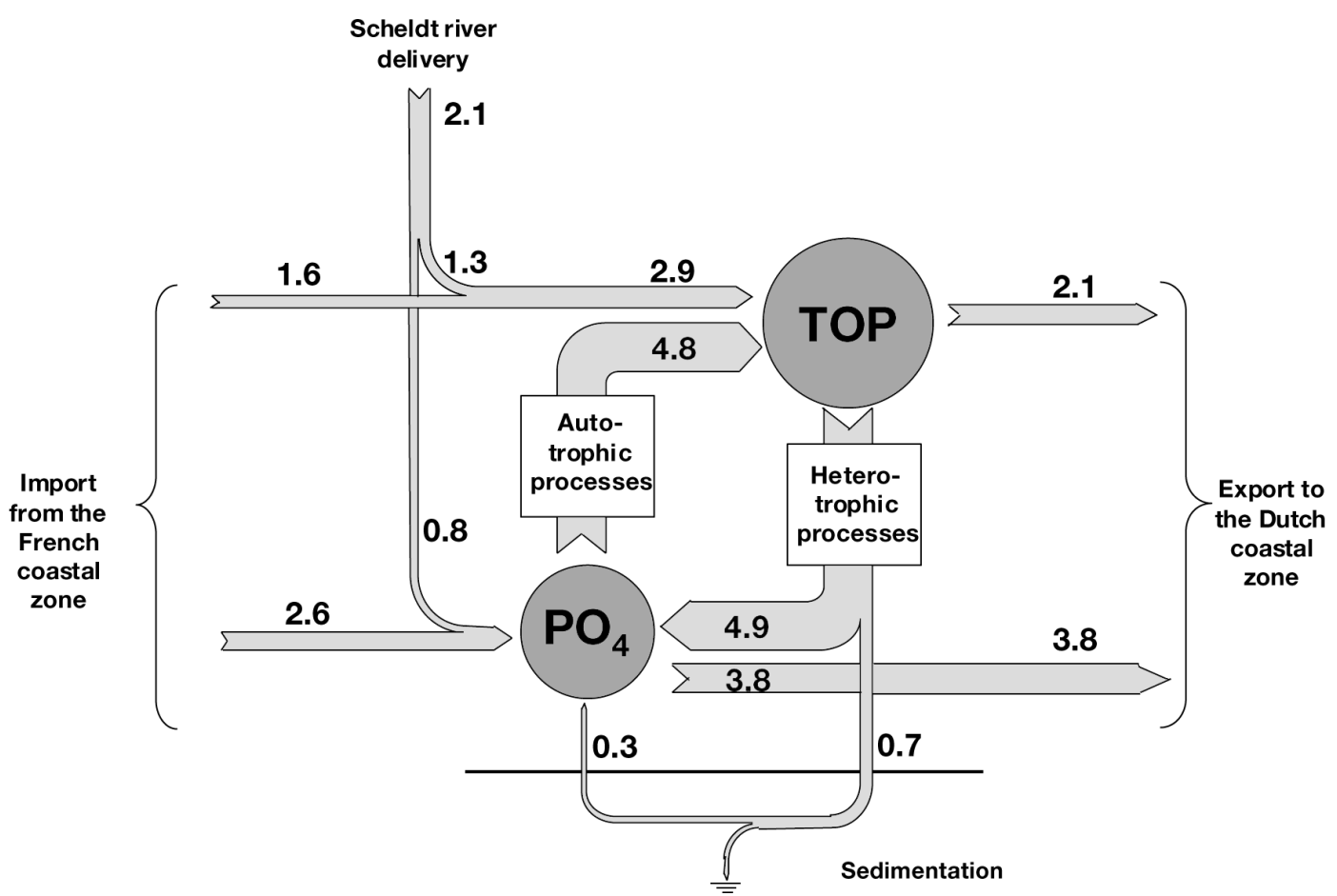

Fig. 7. Annual budget of nitrogen and phosphorus in the Belgian coastal zone, based on MIRO simulations of the daily rates of nutrient uptake and planktonic and benthic mineralization 
based on monthly measurements of benthic oxygen consumption rate at Stn $330\left(25 \mathrm{gC} \mathrm{m}^{-2}\right.$; K. Soetaert pers. comm.). It is, however, low compared to the Joiris et al. (1982) estimate of $160 \mathrm{gC} \mathrm{m}^{-2}$ based on sediment organic matter content and vertical profiles of nutrients in the sediment (Billen 1978). Such a high $C$ input to the sediment is consistent with the higher primary production estimated for that period. However model sensitivity runs with varying sinking rates of diatoms, Phaeocystis colonies and detrital particulate matter (not shown) suggest that the predicted annual input of organic carbon to the sediment is very sensitive to the value attributed to phytoplankton sinking rates. Annual carbon inputs as high as those in Joiris et al. (1982) are obtained at sinking rates of 1 to $2 \mathrm{~m} \mathrm{~d}^{-1}$ (i.e. 5 times higher than in the nominal MIRO run) and have occasionally been measured nearshore (Lancelot et al. 2004). Under such conditions, however, a lower quantity of organic carbon is channelled throughout the microbial loop, contradicting results obtained by Rousseau et al. (2000). Altogether this suggests that the high $\mathrm{N}$ and $\mathrm{P}$ loads in rivers during the late 1970s and early 1980s were stimulating a higher primary production than nowadays for the benefit of the sediment.

\section{Nutrient budget}

Fig. 7 illustrates $\mathrm{N}$ and $\mathrm{P}$ cycling in the BCZ as calculated from MIRO simulations of nutrient uptake and mineralization. A total of $61.5 \mathrm{gN} \mathrm{m}^{-2} \mathrm{yr}^{-1}$ is brought to the area overall, as $\mathrm{NO}_{3}-\mathrm{N}(46 \%), \mathrm{NH}_{4}-\mathrm{N}(10 \%)$, and organic N (44\%). The Scheldt River delivers $46 \%$ of the total $\mathrm{N}$ and $60 \%$ of the $\mathrm{NO}_{3}$ inputs (Fig. 7a). The inflowing Atlantic waters supply $85 \%$ of organic $\mathrm{N}$ (TON). A total annual biological uptake of $27.3 \mathrm{gN} \mathrm{m}^{-2}$ is calculated for the area, of which only $36 \%$ is provided by $\mathrm{NO}_{3}$. Interestingly, the annual $\mathrm{NH}_{4}$ uptake by autotrophs (17.4 $\mathrm{gN} \mathrm{m}^{-2} \mathrm{yr}^{-1}$ ) exceeds the input of $\mathrm{NH}_{4}$ $\left(8.2 \mathrm{gN} \mathrm{m}^{-2} \mathrm{yr}^{-1}\right)$, indicating intense recycling in the area. According to MIRO, $24 \mathrm{~g} \mathrm{NH}_{4}-\mathrm{N} \mathrm{m}^{-2} \mathrm{yr}^{-1}$ are regenerated through planktonic activity (75\%) and benthic diagenesis $(25 \%)$. The latter process also releases $2.2 \mathrm{~g} \mathrm{NO}_{3}-\mathrm{N} \mathrm{m}^{-2} \mathrm{yr}^{-1}$ to the water column. An important part of $\mathrm{NO}_{3}$ regeneration results from water column nitrification. Finally, our model predicts that $60 \mathrm{gN} \mathrm{m}^{-2} \mathrm{yr}^{-1}$ is exported from the area, giving an estimated of $2 \%$ for elimination of $\mathrm{N}$ inputs by benthic denitrification. Nitrogen transformations in the BCZ thus decrease inorganic and organic $\mathrm{N}$ forms flowing out of the area by 3 and $1 \%$, respectively, compared to inflows (Fig. 7a). Altogether the model calculates an increased export of $\mathrm{NH}_{4}$ towards the North Sea (Dutch coastal zone; Fig. 7a).
MIRO estimates an input of $6.26 \mathrm{gP} \mathrm{m}^{-2} \mathrm{yr}^{-1}$ (Fig. 7b), $54 \%$ as inorganic and $46 \%$ as organic $\mathrm{PO}_{4}$. In contrast to simulations of $\mathrm{N}$ inputs, the inflowing Atlantic waters are the most important supply of inorganic P (77\%) compared to the Scheldt River (23\%). The biological uptake of inorganic $\mathrm{P}\left(4.8 \mathrm{gP} \mathrm{m}^{-2} \mathrm{yr}^{-1}\right)$ exceeds the inputs $\left(3.4 \mathrm{gP} \mathrm{m}^{-2} \mathrm{yr}^{-1}\right)$. A total annual $\mathrm{PO}_{4}$ regeneration of $5.2 \mathrm{gP} \mathrm{m}^{-2} \mathrm{yr}^{-1}$ is calculated, of which only $6 \%$ are released at the sediment-water interface. A total of $5.9 \mathrm{gP} \mathrm{m}^{-2} \mathrm{yr}^{-1}$ are exported to the Dutch coastal zone, so that $\mathrm{P}$ retention in the $\mathrm{BCZ}$ sediments is about $4 \%$.

\section{Concluding remarks}

MIRO is the first biogeochemical model based on a mechanistic description of chemical and trophic interactions involved in Phaeocystis-dominated ecosystems. Based on the current ecophysiological properties of Phaeocystis colonies (Schoemann et al. 2004) the model can be used for testing conditions prevailing for Phaeocystis colony dominance in the ocean, and the model has been applied in the Antarctic waters of the Ross Sea (Pasquer et al. 2004). For these model runs an iron parameterisation was added to the current MIRO to consider the iron limitation that characterises this high nutrient-low chlorophyll area (Pasquer et al. 2005).

Multi-box application in different regions of the Eastern Channel and Southern Bight of the North Sea, as well as model sensitivity runs, allowed identification of the conditions prevailing for Phaeocystis bloom and decline in the coastal area, but revealed gaps in knowledge that deserve further experimentation. Parameterisation of Phaeocystis affinity for low $\mathrm{PO}_{4}$ is crucial for the success and magnitude of Phaeocystis blooms along the coastal zone. In comparison, the copepod grazing resistance of Phaeocystis colonies (another factor that may explain bloom success) assumed by the current version of MIRO is not that significant for Phaeocystis success as suggested by MIRO scenarios with small colonies as added food for copepods. Another important issue for the spring-summer food web structure is the parameterisation of colony disruption and the share of Phaeocystis-derived products between NF (release of Phaeocystis colony cells), $\mathrm{DC}_{1}$ (Phaeocystis matrix) and POM (Phaeocystis-derived aggregates) about which little is known. This might show regional differences.

Carbon and nutrient budgets based on MIRO predictions of flow rates show for the first time that the nutrientenriched Belgian coastal waters sustain a planktonic food web with a low $(<10)$ trophic efficiency and that this coastal area has an extremely low retention/elimination capacity with respect to land-based sources of $\mathrm{P}$ and $\mathrm{N}$. 
Finally, model results suggest some sensitivity to the meteorological forcing that modulates both the global solar radiation and the river nutrient loads. The combined effect of changing meteorological conditions and nutrient inputs on Phaeocystis colony blooms over the last decade is analysed in a forthcoming study (Gypens \& Lancelot unpubl).

Acknowledgements. This is a contribution of the AMORE (Advanced MOdeling and Research on Eutrophication) project of the Belgian programme 'Scientific Support Plan for a Sustainable Development Policy_-Sustainable Management of the North Sea' funded by Belgium's Federal Science Policy under Contracts MN/DD/20 and EV-ENZ-05. The work also benefits from results gained in the framework of projects funded by several Belgian North Sea and EU environment programmes since 1988. We are indebted to the captains and crew of RV 'Belgica' and our colleagues from Belgian marine institutions for helping in the weekly sampling of Stn 330. Finally, we thank 4 anonymous reviewers for their constructive comments on the draft.

\section{LITERATURE CITED}

Billen G (1978) A budget of nitrogen cycling in North Sea sediments of the Belgian coast. Estuar Coast Mar Sci 7:127-146

Billen G, Servais P (1989) Modélisation des processus de dégradation bactérienne de la matière organique en milieu aquatique. In: Bianchi M, Marty D, Bertrand JC, Caumette P, Gauthier M (eds) Micro-organismes dans les écosystèmes océaniques. Masson, Paris, p 219-245

Billen G, Dessery S, Lancelot C, Meybeck M (1989) Seasonal and interannual variations of nitrogen diagenesis in the sediments of a recently impounded basin. Biogeochemistry $8: 73-100$

Billen G, Garnier J, Rousseau V (2005) Nutrient fluxes and water quality in the drainage network of the Scheldt basin over the last 50 years. Hydrobiologia in press

Breton E, Sautour B, Brylinski JM (1999) No feeding on Phaeocystis sp. as solitary cells (post bloom period) by the copepod Temora longicornis in the coastal waters of the English Channel. Hydrobiologia 414:13-23

Brussaard C, Riegman R, Noordeloos A, Cadée G and 5 others (1995) Effects of grazing, sedimentation and phytoplankton cell lysis on the structure of a coastal pelagic food web. Mar Ecol Prog Ser 123:259-271

Cadée GC (1996) Accumulation and sedimentation of Phaeocystis globosa in the Dutch Wadden Sea. J Sea Res 36: 227-230

Canziani GA, Hallam TG (1996) A mathematical model for a Phaeocystis sp. dominated plankton community dynamics. I. The basic model. Nonlinear World 3:19-76

Estep KW, Nejstgaard JC, Skjoldal HR, Rey F (1990) Predation by copepods upon natural populations of Phaeocystis pouchetii as a function of the physiological state of the prey. Mar Ecol Prog Ser 67:235-249

Fasham MJR, Sarmiento JL, Slater RD, Ducklow HW, Williams R (1993) Ecosystem behaviour at Bermuda Station 'S' and Ocean Weather Station 'India': a general circulation model and observational analysis. Global Biogeochem Cycles 7(2):379-415

Friedrichs MAM, Hofmann EE (2001) Physical control of biological processes in the central equatorial Pacific Ocean. Deep-Sea Res Part I 48:1023-1069
Gasparini S, Daro MH, Antajan E, Tackx M, Rousseau V, Parent JY, Lancelot C (2000) Mesozooplankton grazing during the Phaeocystis globosa bloom in the Southern Bight of the North Sea. J Sea Res 43:345-356

Hansen B, Verity P, Falkenhaug T, Tande KS, Norrbin F (1994) On the trophic fate of Phaeocystis pouchetii (Harriot). V. Trophic relationships between Phaeocystis and zooplankton: an assessment of methods and size dependence. J Plankton Res 16(5):487-511

Hansen FC (1992) Zooplankton-grazing an Phaeocystis mit besonderer Berücksichtigung der calanoiden Copepoden. $\mathrm{PhD}$ thesis, University of Kiel

Joiris C, Billen G, Lancelot C, Daro MH, Mommaerts JP, Bertels A, Bossicart M, Nijs J (1982) A budget of carbon cycling in the Belgian coastal zone: relative role of zooplankton, bacterioplankton and benthos in the utilization of primary production. Neth J Sea Res 16:260-275

Laevastu T (1963) Surface water types of the North Sea and their characteristics. Serial Atlas of the Marine Environment, Folio 4. American Geographical Society, New York

Lancelot C (1995) The mucilage phenomenon in the continental coastal waters of the North Sea. Sci Total Environ 165:83-102

Lancelot C, Billen G (1985) Carbon-nitrogen relationship in nutrient metabolism of coastal marine ecosystem. Adv Aquat Microbiol 3:263-321

Lancelot C, Mathot S (1985) Biochemical fractionation of primary production by phytoplankton in Belgian coastal waters during short- and long-term incubations with ${ }^{14} \mathrm{C}$ bicarbonate. II. Phaeocystis pouchetii colonial population. Mar Biol 86(3):227-232

Lancelot C, Billen G, Sournia A, Weisse T, Colijn F, Veldhuis M, Davies A, Wassman P (1987) Phaeocystis blooms and nutrient enrichment in the continental coastal zones of the North Sea. Ambio 16:38-46

Lancelot C, Veth C, Mathot S (1991) Modelling ice edge phytoplankton bloom in the Scotia-Weddell Sea sector of the Southern Ocean during spring 1988. J Mar Syst 2: 333-346

Lancelot C, Billen G, Rousseau V (1994) Modelling Phaeocystis blooms, their causes and consequences. Final Rep, EU Programme Science and Technology for Environmental Protection (STEP). Commission of the European Communities, Brussels

Lancelot C, Rousseau V, Billen G, Van Eeckhout DV (1997) Coastal eutrophication of the Southern Bight of the North Sea: assessment and modelling. In: Ozsoy E, Mikaelyan A (eds) Sensitivity to change: Black Sea, Baltic Sea and North Sea. Kluwer, Dordrecht, p 437-454

Lancelot C, Rousseau V, Becquevort S, Parent JY and 9 others (2004) Study and modelling of eutrophication-related changes in coastal planktonic food-webs: a contribution of the AMORE (Advanced MOdeling and Research on Eutrophication) consortium. Final report. In: Scientific support plan for a sustainable development policysustainable management of the North Sea. Belgian Science Policy, Brussels

Lancelot-Van Beveren C (1980) A statistical method to estimate the biochemical composition of phytoplankton in the Southern Bight of the North Sea. Estuar Coast Mar Sci 10: 467-478

Lawson LM, Spitz YH, Hofmann EE, Long RB (1995) A data assimilation technique applied to a predator-prey model. Bull Math Biol 57:593-617

Nejstgaard JC, Hansen Hygum B, Naustvoll LJ, Båmstedt U (2001) Zooplankton growth, diet and reproductive success compared in simultaneous diatom- and flagellate- 
microzooplankton-dominated plankton blooms. Mar Ecol Prog Ser 221:77-91

Officer CB, Ryther JH (1980) The possible importance of silicon in marine eutrophication. Mar Ecol Prog Ser 3:83-91

Olsen Y, Reinertsen H, Vadstein O, Andersen T and 11 others (2001) Comparative analysis of food web based on flow networks: effects of nutrient supply on structure and function of coastal plankton communities. Cont Shelf Res 21: 2043-2053

O'Neill RV, De Angelis DL, Pastor JJ, Jackson BJ, Post WM (1989) Multiple nutrient limitations in ecological models. Ecol Model 46:147-163

Pasquer B, Laruelle G, Goosse H, Lancelot C (2005) Linking ocean biogeochemical cycles and ecosystem structure and function: results of the complex SWAMCO-4 Model. J Sea Res 53:93-108

Peperzak L, Colijn F, Gieskes WWC, Peeters JCH (1998) development of the diatom-Phaeocystis spring bloom in the dutch coastal zone of the North sea: the silicon depletion versus the daily irradiance threshold hypothesis. J Plankton Res 20:517-537

Peperzak L, Colijn F, Koeman R, Gieskes WWC, Joordens A (2003) Phytoplankton sinking rates in the Rhine region of freshwater influence. J Plankton Res 25(4):365-383

Radach G, Pätsch J, Gekeler J, Herbig K (1995) Annual cycles of nutrients and chlorophyll in the North Sea. Ozeanographie Berichte 20, Zentrum für Meeres- und Klimaforschung

Redfield AC, Ketchum BA, Richards FA (1963) The influence of organisms on the composition of sea-water. In: Hill MN (ed) The sea, Vol 2. Wiley, New York, p 26-77

Riebesell U (1993) Aggregation of Phaeocystis during spring bloom in the southern North Sea. Mar Ecol Prog Ser 96: 281-289

Rousseau V, Mathot S, Lancelot C (1990) Calculating carbon biomass of Phaeocystis sp. from microscopic observations. Mar Biol 107:305-314

Rousseau V, Vaulot D, Casotti R, Cariou V, Lenz J, Gunkel J, Bauman M (1994) The life-cycle of Phaeocystis (Prymnesiophyceae): evidence and hypotheses. J Mar Syst 5(1): 23-39

Rousseau V, Becquevort S, Parent JY, Gasparini S, Daro MH, Tackx M, Lancelot C (2000) Trophic efficiency of the planktonic food web in a coastal ecosystem dominated by Phaeocystis colonies. J Sea Res 43:357-372

Rousseau V, Leynaert A, Daoud N, Lancelot C (2002) Diatom succession, silicification and silicic acid availability in

Editorial responsibility: Otto Kinne (Editor-in-Chief), Oldendorf/Luhe, Germany
Belgian coastal waters (Southern Bight of the North Sea) Mar Ecol Prog Ser 236:61-73

Rousseau V, Breton E, De Wachter B, Beji A and 6 others (2004) Identification of Belgian maritime zones affected by eutrophication. In: Scientific support plan for a sustainable development policy-sustainable management of the North Sea. Belgian Science Policy, Brussels

Schoemann V, de Baar HJW, de Jong JTM, Lancelot C (1998) Effects of phytoplankton blooms on the cycling of manganese and iron in coastal waters. Limnol Oceanogr 43(7): $1427-1441$

Schoemann V, Becquevort S, Stefels J, Rousseau V, Lancelot C (2005) Phaeocystis blooms in the global ocean and their controlling mechanisms: a review. J Sea Res 53:43-66

Sournia A, Birrien JL, Douvillé JL, Klein B, Viollier M (1987) A daily study of the diatom spring bloom at Roscoff (France) in 1985. I. The spring bloom within the annual cycle. Estuar Coast Shelf Sci 25:355-367

Spitz YH, Moisan JR, Abbott MR, Richman JG (1998) Data assimilation and a pelagic ecosystem model: parameterization using time series observations. J Mar Syst 16:51-68

Spitz YH, Moisan JR, Abbott MR (2001) Configuring an ecosystem model using data from the Bermuda-Atlantic Time Series (BATS). Deep-Sea Res Part II 48:1733-1768

Turner RE, Qureshi N, Rabalais NN, Dortch Q, Justic D, Shaw RF, Cope J (1998) Fluctuating silicate:nitrate ratios and coastal plankton food webs. Proc Natl Acad Sci USA 95: 13048-13051

Veldhuis MJW, Admiraal W (1985) Transfer of photosynthetic products in gelatinous colonies of Phaeocystis pouchetii (Haptophyceae) and its effect on the measurement of excretion rate. Mar Ecol Prog Ser 26:301-304

Veldhuis MJW, Admiraal W (1987) Influence of phosphate depletion on the growth and colony formation of Phaeocystis pouchetii. Mar Biol 95:47-54

Veldhuis MJW, Colijn F, Venekamp LAH (1986) The spring bloom of Phaeocystis pouchetii (Haptophyceae) in Dutch coastal waters. Neth J Sea Res 20:37-48

Veldhuis MJW, Colijn F, Admiraal W (1991) Phosphate utilization in Phaeocystis pouchetii (Haptophyceae). Mar Ecol Prog Ser 12:53-62

Verity PG (2000) Grazing experiments and model simulations of the role of zooplankton in Phaeocystis food webs. J Sea Res 43:317-343

Weisse T, Scheffel-Möser U (1990) Growth and grazing loss in single-celled Phaeocystis sp. (Prymnesiophyceae). Mar Biol 106:153-158

Submitted: February 12, 2004; Accepted: November 9, 2004 Proofs received from author(s): March 2, 2005 